\title{
Supraglottic Verrucous Carcinoma
}

National Cancer Institute

\section{Source}

National Cancer Institute. Supraglottic Verrucous Carcinoma. NCI Thesaurus. Code C8191.

An exophytic, slow growing, well differentiated and non-metastasizing squamous cell carcinoma with pushing margins that arises from the supraglottic area of the larynx. 